\title{
TAJEMSTVÍ VELIKONOC V BYZANTSKÉM RITU PROSTŘEDNICTVÍM MYSTICKO-TEOLOGICKÉ REFLEXE
}

\author{
K A R E L S LÁ D E K
}

To je ten, který sestoupil z nebes na zemi kvůli trpícimu, toho si oblékl v lůné, a jako človèk prìšel na svèt, príijal utrpeni toho, kdo trpèl, a skrze tèlo, podrobené utrpení, zničil utrpeni tẻla; a Duchem, který nemůže zemrít, zabil smrt, zabijejicí človèka. ${ }^{1}$

Melitón ze Sard

\section{$\mathrm{V}$}

uvedené citaci z pera Melitóna ze Sard je básnickým stylem představeno teologické tajemství slavení Velikonoc. Sebevydání druhé božské Osoby odhalené již v okamžiku vtělení předznamenává vrcholný čin spásy v pokorném podstoupení utrpení a smrti, která je „Zabita“"vzkříšením Ježíše Krista. Slavení tajemství Velikonoc je cestou vnitřní proměny: od smrti ke vzkříšení za spolupůsobení Osob Boží Trojice. V tomto článku se zaměřím na interpretaci tajemství Velikonoc $\mathrm{v}$ byzantském ritu prostřednictvím mysticko-teologické reflexe, respektive skrze duchovní rozvoj osobnosti, jak je pojímán v křestanské mystické tradici. Mystická teologie, ${ }^{2}$ jak ji nazývají ortodoxní teologové, je ztotožnitelná s oborem, který se v rámci teologických disciplín křestaanského Západu nazývá spirituální teologie. ${ }^{3}$

1 MELITÓN ZE SARD. O Pasše. Červený Kostelec: Pavel Mervart, 2010, s. 131-132.

2 Mystickou teologii ve východokřestanské spiritualitě můžeme definovat jako teologickou disciplínu usilující o poznání rozmanitých cest proměny lidské přirozenosti v boholidskou v rámci mystického výstupu, ve kterém je člověk prostřednictvím liturgicko-sakramentálního života Církve zbožštěn božskými energiemi a formován nestvořeným světlem milosti, čímž postupně vrůstá do tajemství láskyplného života Boží Trojice - srov. SLÁDEK, Karel. Mystická teologie východoslovanských křestanů. Červený Kostelec: Pavel Mervart, 2010, s. 59-61.

3 Pavel Vojtěch Kohut definuje spirituální teologii takto: „Spirituální teologie je teologická disciplína, která na základě biblického Zjevení a kvalifikované křestanské zkušenosti systematicky studuje sjednocení člověka s trojjediným Bohem v Kristu, k němuž dochází působením Ducha svatého v dějinách církve a světa a lidskou spoluprací, a popisuje jeho organický rozvoj od počátku až po dosažení svatosti se zohledněním 
Článek je svojí strukturou rozdělen chronologicky, podle následnosti dní liturgického období, přičemž začneme od přípravy na Velikonoce a text ukončíme meditací o velikonočním triduu. Metodou je aplikace nauky o duchovním rozvoji osobnosti prostřednictvím cesty obrácení, očištění, osvícenía sjednocení na jednotlivé dny slavení tajemství Velikonoc v byzantském ritu. Použité prameny pro podložení mysticko-teologických reflexí jsou jak primárního charakteru (evangelijní příběhy, velikonoční liturgické texty byzantského ritu), tak sekundárního (odborné monografie o interpretaci Velikonoc z pera východních teologů, především od ruských autorů a jejich nástupců).

\section{Postní příprava na Velikonoce a vstup do Velkého strastného týdne}

Před dobou velikonoční se v tradici církví Západu i Východu nachází liturgické období Velkého půstu. Postní praxe vrcholí v posledním týdnu před Velikonocemi, který se na v Východě nazývá Velký strastný týden. Podle př́sné tradice půst tohoto týdne zahrnuje suchou stravu po třetí hodině odpolední a na Velký pátek by se nemělo jíst vůbec. Na Velkou sobotu je také přísný půst, načež se jí až večer pro posilnění před celonočním bděním. Vnější askeze je nemyslitelná bez askeze vnitřní, bez pokání a projevu milosrdenství, jak uvádí následující kon$d a k^{4}$ doby postní:

Nyní nastal čas ke skutkům, soud je přede dveřmi. Povstaňme tedy k postu, přinesme slzy lítosti, čiňme skutky milosrdenství.

V době postní se kromě sobot, nedělí, Velkého čtvrtku a 25. března (slavnost Zvěstování Páně) slouží Liturgie předposvěcených darů. Během léto liturgie kněz odř́kává následně uvedenou modlitbu sv. Efréma, která výstižným způsobem uvádí do spirituality této liturgické doby:

Pane a Vládce mého života, zažeň ode mě ducha lenivosti, pohrdání, touhy po moci a prázdných řečí. Daruj mi, svému služebníku, ducha čistoty, pokory,

rozmanitosti a neopakovatelnosti jednotlivých cest.“ - KOHUT, Pavel Vojtěch. Co je spirituálni teologie?. Kostelní Vydří: Karmelitánské nakladatelství, 2007, s. 34.

4 Kondak je zpívaný hymnus v liturgii byzantského ritu shrnující teologické tajemství svátků nebo charakteristické vlastnosti světce - viz též FARUGGIA, Edward (ed.). Encyklopedický slovnik krestanského Východu. Olomouc: Refugium, 2008, s. 487-488. 
trpělivosti a lásky. Ano, Pane a Králi, dej, abych poznal své hříchy a neodsuzoval svého bratra, nebot' jsi požehnaný nyní i vždycky a na věky věků. Amen.

Půst - jak se kněz modlí v této modlitbě svatého Efréma - zahrnuje jak aktivní boj proti egoistickým vášním (lenivost, pohrdání, touha po moci, prázdné řeči), tak disponování se pro působení „ducha čistoty, pokory, trpělivosti a lásky“. Autentičnost postní praxe prozrazuje vnitřní postoj pokání v poznání vlastních hříchů a v oproštěnosti od souzení druhých lidí. Postní „vnější“ omezení má člověka lépe disponovat pro „vnitřní“ usebrání, zamezit rozptylování mysli, aby se soustředil a hlouběji meditoval o Božím zjevení a událostech spásy. Během postní doby by se proto měl věřící pečlivěji věnovat Božímu slovu. Liturgické texty Velkého strastného týdne nabízejí rozjímat o následujících příbèzích z evangelií: po Kvètné nedèli, vstupu Ježíše do Jeruzaléma, následuje Velké pondélí, kdy je čten úryvek o Ježíšem zavrhnutém neplodném fíkovníku; Velké úterý otevírá téma moudrých družiček a Velká středa medituje o hříšnici, která líbala nohy Ježíše Krista, čímž tělesně projevila neskonalou lásku. Tímto evangelijním úryvkem o projevené lidské lásce, kterou Ježíš přijímal a hájil, uvádějí biblické texty následujícího dne do tajemství lásky Boha skrze ustanovení nové a věčné smlouvy: eucharistie. Ustanovení eucharistie je v liturgické tradici ortodoxní i katolické církve připomínáno na Velký čtvrtek.

\section{Velký čtvrtek: střet mezi agapickou láskou a filautickou sebeláskou}

Na Velký čtvrtek se připomíná ustanovení poslední večeře Páně, což je zpřítomňováno slavnostním slavením Božské liturgie sv. Basila Velikého, po které biskup umývá nohy kněžím. V tento den se odhaluje dvojí láska: agapická Krista a egoistická Jidáše. Alexander Schmemann o projevu spásné a patologické lásky napsal:

Poslední večeře je konečné zjevení výkupné lásky Boha k člověku, lásky jakožto vlastní podstaty spásy. A zrada Jidáše ukazuje, že hřích, smrt a sebezničení přichází také z lásky, ale z lásky znevážené a pokřivené, obrácené k tomu, co si ani nezaslouží být milováno. ${ }^{5}$

5 SCHMEMANN, Alexander. La settimana santa. In SCHMEMANN, Alexander - CLÉMENT, Olivier. Il mistero pasquale. Roma: Lipa, 2003, s. 19-20. 
Dvojí láska se vyjeví v kontrastu: jedna je esencí spásy, druhá hříchu. Setkání s Boží láskou, tzv. agapé (z řeckého àyóđ̃ označující v křestanské spiritualitě lásku, která předává přijatý dar ${ }^{6}$ ), jež se zjeví v daru nové a věčné smlouvy (eucharistie), přivádí člověka k sebepoznání, jež může vést bud' do tmy Jidášových činů, nebo k vnitřnímu obrácení. Duchovní zkušenost obrácení doprovází setkání s vlastní nedokonalostí a s poznáním působení zla v člověku a v tomto světě. Působení této egoistické sebelásky, tzv. filautie (z řeckého pı $\lambda \alpha v \tau i \alpha$, která je v nauce Maxima Vyznavače považována za pramen všech špatných myšlenek ${ }^{7}$ ), se po ustanovení eucharistie demaskuje právě v konání Jidáše. Poznání reality života zahrnuje i vhled do působení hříchu, což na druhou stranu umožňuje hlouběji poznat a prožít výkupnou lásku Boha, jak v následné citaci poznamenal Vladimír Solovjov:

Smysl křestanství ani nemůže být jasný pro ty, kteří se cítí dobře v tomto světě. Pro takové lidi i Kristovo kázání bylo němým slovem, protože neviděli zlo, z kterého Kristus přišel vysvobodit svět. ${ }^{8}$

Velikonoční triduum byzantského ritu svými evangelijními texty, liturgickými úkony i asketickou praxí přivádí věřícího k pravdivému sebepoznání. Sebezkušenost v odvážném setkání s vlastním hříchem je odrazovým můstkem pro proměnu v lásce. Aby obrácený člověk postoupil na své duchovní cestě, prochází cestou očištování (via purgativa) od vžitých mechanismů egoistické sebelásky zviditelněné v Jidášových činech. Jidáš polibkem zradil Syna člověka. Věřící veřejně odmítají tuto filautickou lásku před přijímáním eucharistie (agapické lásky), když se v byzantské liturgii modlí:

Přijmi mě dnes, Synu Boží, k účasti na své tajemné večeři, vždyt' nechci toto tajemství vydat nepřátelům ani tě pozdravit jidášským políbením, ale jako lotr se ti vyznávám: Pamatuj na mne, Pane, ve svém království.

Jak již bylo několikrát uvedeno, před dokonalou láskou smluvně ukotvenou v eucharistii se demaskuje přízemní princip zla spoutávající lidstvo po Adamově pádu. Radikální láska Boha vyprovokovala

\footnotetext{
Srov. BENEDIKT XVI. Deus caritas est. Praha: Paulínky, 2006, s. 15.

Srov. FARUGGIA, Edward (ed.). Encyklopedický slovnik krestanského Východu, s. 338. SOLOVJOV, Vladimír. Duchovni základy života. Olomouc: Refugium, 1996, s. 71.
} 
extrémní protireakci zlého, která ale - jak bude uvedeno v následujících mysticko-teologických reflexích nad byzantskými Velikonocemi - nezvítězí, i když využije a použije lidské slabosti a porušenosti, včetně nejdokonalejšího nástroje zla: násilí a smrti.

\section{Velký pátek: od úzkosti a strachu k důvěře a odevzdání}

Na Velký pátek je v byzantském ritu čteno dvanáct úryvků z evangelií, které popisují křížovou cestu Ježíše Krista. Během utrpení a smrti Krista se demaskuje působení zla $\mathrm{v}$ jeho nahotě, přičemž paradoxně se Kristovo utrpení nestává porážkou, ale cestou spásy pro lidstvo. Bůh člověka zachraňuje tím, že na sebe bere jeho hřích, jeho stav opuštěnosti, zoufalství, a učí pokorné důvěře. Olivier Clément v této myšlenkové linii reflektuje událost v Getsemanech a na Golgotě:

Když toto tělo v Getsemanech a na Golgotě pojímá všechny naše smrtelné zápasy, když Slovo lidsky, tělesně zakouší naše úzkosti a muka, je už jen rozbitým tělem vystavěným posměchu lidí a Otec mlčí, vše se rázem zaplavuje světlem; nepředstavitelná propast, kterou v Božím nitru vyhloubilo Ježíšovo lidské zoufání, všezahrnující zoufání, „Bože můj, Bože můj, proč jsi mě opustil?“, se vyplňuje svatým Dechem, který všechno sjednocuje: „Otče, do tvých rukou odevzdávám svého ducha!“, a toho ducha, tohoto Ducha odevzdává též Marii a Janovi, první církvi u paty křiže. A vše se obrací, „tělo pro smrt“ se stává „tělem pro vzkř̌išení“. Naše smrt, všechny smrti, které přestřihují náš život, se stávají cestou ke vzkř̌í̌ení. ${ }^{9}$

Pokušení pocitu opuštěnosti Bohem, temné noci, bezvýchodnosti, které je zahrnuto v citované modlitbě Krista na křiži, odráží stav člověka po prvotním pádu. Ilarion Alfejev, když popisuje život a duchovní odkaz Izáka Syrského, představuje nauku toho významného duchovního autora v analogické mystické perspektivě. Opuštěnost Bohem je podle Izáka nejstrašnější zkouška, období duchovního úpadku, který záhy vystřídá vzestup a útěcha. Ilarion Alfejev konkrétně napsal:

Život v Bohu spočívá v prožívání Boží přítomnosti. Když je tento pocit z jakéhokoliv důvodu oslaben, věřící nedojde pokoje, dokud se nevrátí. V tomto smyslu je opuštěnost Bohem nejvyšším stupněm „krize“, tj. soudu, na kterém jsou spravedliví odděleni od nespravedlivých. Zkušenost opuštěnosti

9 CLÉMENT, Olivier. Télo pro smrt a pro slávu. Olomouc: Refugium, 2004, s. 25. 
Bohem má pro každého křestana pouze dvě možná řešení - bud' prohloubení víry a přiblížení se k Bohu, nebo „ztroskotání ve víře“ a ztrátu Boha. ${ }^{10}$

Ježíš proměňuje lidskou beznaděj v naději a zoufalství v radost, „úzkost se přetváří v důvěru a narcismus v odevzdanost..."11 Utrpení a kříž Ježíše je totiž projevem „ontologické solidarity“, jak napsal Olivier Clément:

I na křiži Ježiš zvolá mocným hlasem $(\operatorname{Lk} 23,46)$ a v Getsemanech se potí krví. Tehdy ve své ontologické solidaritě s námi zakouší protipřirozenost smrti a všech našich situací smrti, a protože on je jediný plně žijící, cítí je v celé jejich tíži. Olovnicí svého proměněného a ukřižovaného lidství měří hloubku oddělení člověčenství pohřbeného v utrpení, smrti a podsvětí. Smrt totiž nepochází z jeho bytí, ale jen z jeho lásky k nám. My jsme uvnitř smrti. On jí byl cizí, ale „sestoupil“ do ní. Bůh protrpěl smrt v těle, lidsky podstoupil smrt, řekl Pátý ekumenický koncil. ${ }^{12}$

Přijetí křiže znamená umožnit proměnu vlastní přirozenosti v novou boholidskou přirozenost. ${ }^{13}$ Pavel Evdokimov velmi citlivě psal o přijetí vlastního kř́že v souvislosti s niterným poznáním křižze Krista:

Otcova tvář přechází v Synovu a do našeho nitra padne stín jeho kř̌že.e Náš vlastní kříž se jasně rýsuje, už není návratu k dřívější prosté a dětské víře. Duši drásají bolestné disonance, jasně vidí zlo a hřích, prožívá krajní napětí mezi dvěma stavy, které se vzájemně vylučují. Krutá zkušenost pádů a nemohoucnosti ji může vrhnout na pokraj zoufalství. Jsme ve velkém pokušení křičet, že je to nespravedlivé, říkat, že Bůh na nás žádá př́lišs, že náš kříž je těžší než křiž těch druhých,

píše Evdokimov a dodává:

Člověk nikdy není zkoušen nad své síly. Bůh na nás v tomto rozhodujícím okamžiku napjatě čeká. Očekává od naší víry mužný čin, plné a vědomé přijetí vlastního údělu; chce, abychom jej přijali svobodně. ${ }^{14}$

10 ALFEJEV, Ilarion. Izák Syrský a jeho duchovní odkaz. Červený Kostelec: Pavel Mervart, 2010, s. 126.

11 CLÉMENT, Olivier. Tëlo pro smrt a pro slávu, s. 34.

12 Tamtéž, s. 122-123.

13 Srov. SLÁDEK, Karel. Mystická teologie východoslovanských křestanů. Červený Kostelec: Pavel Mervart, 2010, s. 83-85.

14 EVDOKIMOV, Pavel. Epochy duchovniho života. Od pouštnich Otců do našich dní. Olomouc: Refugium, 2002, s. 76-77. 
Rovněž tvar samotného kříže je znamením sestoupení a zároveň výstupu. Vertikála křiže je v ikonické tradici zasazena do země s lebkou (Adamovou hlavou, která předznamenává sestup do předpeklí), a zároveň směřuje k nebi, ke vzkř́íšení. Na tvaru kříže je podle východní křestanské tradice umístěno třetí příčné dřevo, jež je lehce nakloněné. Pavel Evdokimov tuto symboliku dává do souvislosti se soudem:

Scabellum pedum (srv. Sk 2,35; Žl 109) skloněné dolů zobrazuje osud lotra po levici a skloněné nahoru osud lotra po pravici kříže. Kř́ž, „,váhy spravedlnosti“ a průlom do věčnosti, je uprostřed jako most mezi nebeským královstvím a peklem. ${ }^{15}$

Připomínka postoje lotra po pravici je zmíněna $\mathrm{v}$ již citované modlitbě věřícího před přijetím eucharistie. Kříž má tedy i rozměr soudu: konečné oddělení lásky ráje od pekelských muk zhoubné sebelásky. Podle Vladimíra Losského je zároveň znamením sebevydanosti celé Boží Trojice. Je Její svobodnou volbou vzít na sebe pro spásu člověka následky jeho hříchu. Je Jejím svobodným sebeponížením až do krajnosti, čímž byla zjevena mírná a obětavá láska Syna vydaného do rukou nepřátel. ${ }^{16}$ Následování Krista v přijetí vlastního kříže či nesení kříže bližních znamená intimně se připodobňovat Jeho boholidské přirozenosti. Sergej Bulgakov míní, že když člověk na sebe vezme kříž, může to „také mít zcela objektivní význam, protože v něm dochází ke koordinaci mezi Božskou a lidskou vůlí. Kř̌́ž je otázka, obracející se na lidskou vůli a jeho přijetí je kladná odpověd' na ni, rodící se z mírnosti srdce.“17 Rovněž podle Bulgakova je v okamžiku smrti Ježíše Krista přítomno též sebevydání Ducha svatého. Když byl Ježíš uložen do hrobu, Duch svatý zůstává s ním, takže jeho tělo je neporušeno. Následně s Kristem sestupuje do předpeklí a účastní se Jeho Vzkř́í̌ení. ${ }^{18}$

Večerní bohoslužba Velkého pátku je v byzantském ritu spojena s procesním vynášením přikrývky na hrob, tzv. pláśčenice (z ruského плащаница), na níž je vyšitý nebo namalovaný Kristus sejmutý z křiže a kladený do hrobu. Plátno je přeneseno z oltáře do chrámové lodi, kde se klade na květinami vyzdobený stůl představující Boží hrob. ${ }^{19}$

15 Tamtéž, s. 95-96.

16 Srov. LOSSKIJ, Vladimir. Очерк мистического богословия восточной иеркви. Догматическое богословие. Moskva: Centrum „SEI“, 1991, s. 115-118.

17 BULGAKOV,Sergej. Nevésta Beránkova (OBoholidstvi). Velehrad:Refugium, 2004, s. 291.

18 Srov. BULGAKOV, Sergej. Il Paraclito. Bologna: EDB, 1987, s. 339-592.

19 Srov.FARUGGIA, Edward (ed.).Encyklopedickýslovnikkrestanského Východu, s. 695-696. 
Věřící bdí u hrobu, učí se být s Kristem a po vzoru Ducha svatého být svědkem jeho sestupu a výstupu. Po cestě velkopátečního očištování (mnohdy i během) následuje zkušenost s cestou osvícení (via illuminativa) Slovem Vzkříšeného. Světlo radostné zvěsti bylo nejprve zvěstováno v místech života spravedlivých zemřelých. A až následně bylo hlásáno v pozemském světě. Takové je tajemství Velké soboty.

\section{Velká sobota: sestoupení do předpeklí jako zvěstování a předobraz křtu}

Spiritualitu Velké soboty doprovází tajemství Kristovy smrti a Jeho sestoupení do předpeklí. Ježíš podle křestanské tradice sestoupil hlásat radostnou zvěst všem těm spravedlivým, kteří v posmrtném stavu očekávali na vstup do nové dimenze bytí. Velká sobota je událostí znovu umožňující věčný život v ráji. Již kondak doby postní připomíná věřícím tuto rozhodující událost:

Nebrání už více plamenný meč bránu Edenu, otevřel ji náš přeslavný spojenec: dřevo Křriže. Byl zapuzen osten smrti a zahnáno vítězství pekla, nebot' tys, Spasiteli můj, v něm stanul a volal jsi k těm, kdo byli v podsvětí: „Vejděte opět do ráje!“

A následující kondak Květné neděle dává do souvislosti událost sestupu s „novým“ povoláním Adama, který překonává stav porušení přijetím Božího slova, čímž „nově“ participuje na Vzkř́íšení:

Kriste, Bože, jenž spočíváš na nebesích na trůně i na zemi sedíš na oslátku, přijal jsi chvalozpěv andělů i opěvování dětí volajících: „Požehnaný, jenž přichází, aby povolal Adama.“

Taktéž podle následujícího liturgického zpěvu Velké soboty Ježíš nejprve sestoupil na zem, aby zde hledal Adama, a po té se kvủli jeho záchraně vydal do předpeklí:

Sestoupil jsi na zem, abys zachránil Adama, a když jsi ho tam nenalezl, vydal ses ho hledat až do pekel.

Kromě zvěstování Božího slova o vykoupení v místě předpeklí je událost Velké soboty svázána se svátostí křtu. Během křtu je podle starodávné tradice celý člověk třikrát ponořen do vod, tedy třikrát sestupuje, 
a je třikrát knězem vytažen do nového bytí. ${ }^{20}$ Analogicky Kristus sestoupil do předpeklí, kde podle ikonického ztvárnění vzal za ruku Adama a Evu, aby vtáhl je do nového života. Pavel Evdokimov k tomu napsal:

Být pokřtěn tedy znamená nejen zemřít a být vzkř̌išen s Kristem, ale také sestoupit do pekel a za Kristem z nich vyjít. Vždyt́ peklo je hroznější než smrt. Vybavují se nám zde slova jednoho Otce: „A nicota, kterou hledají, jim nebude dána.“ A právě zde bylo vydobyto definitivní vítězství. Kristus sem sestupuje obtížený Hříchem, se stigmaty Křiže, ukřižované Lásky. Musíme mít pevně na paměti konečné a bezprostřední důsledky: každý pokřtěný, vzkřrí̌sený spolu s Kristem, též nese stigmata kněžských starostí Krista-Kněze, jeho apoštolské úzkosti o osud těch, kdo jsou v pekle. ${ }^{21}$

Spiritualita pokřtěného člověka je stigmatizována následováním Krista až do předpeklí, do nicotnosti světa, bojem proti vlastnímu peklu a nesením trpkého údělu druhých, prožitím jejich zoufalství v životě bez Boha, totální samoty, do které má být zvěstováno světlo radostné zvěsti. Evdokimov přirovnává tento duchovní prožitek k mystice noci:

„Noc“ západních mystiků a „opuštěnost Bohem“ duchovních učitelů křestanského Východu promlouvají o sestoupení do pekel. Ten, kdo je vnímavý ke světu, prožívá zkušenost pekla bezprostředně. ${ }^{22}$

Dále si Evdokimov všímá zobrazení tajemství sestoupení do předpeklí v ikonografii. Symbolicky je připomínáno již na Ikoně Narození, kde leží Ježíš ovinutý stejným plátnem jako v hrobě a na pozadí temné jeskyně - symbolu místa mrtvých, kam sestoupí po své smrti. Taktéž Ikona Epifanie s Ježíšem vstupujícím do vod Jordánu je jakoby tekutým hrobem, který obtéká celého Krista. Vlastní Ikona Sestoupeni do préedpekli je ikonou zvěstování, kdy Ježíš oklopen zářící aureolou svého oslaveného těla drží svitek se zvěstí o svém vzkříšení, šlape po branách pekla a drží za ruku Adama. ${ }^{23}$ A ihned poté vychází z tohoto místa mrtvých, „ze zničeného pekla jako ze svatebního paláce“24, k lidem žijícím na zemi, aby i jim byla zvěstována radostná zvěst o vzkř́išení a věčném životě. A nastává Nedéle Paschy.

20 Srov. EVDOKIMOV, Pavel. L'Ortodoxie. Paris: Declée De Brouwer, 1979, s. 275.

21 EVDOKIMOV, Pavel. Epochy duchovniho života, s. 97.

22 Tamtéž, s. 110.

23 Srov. tamtéž, s. 96.

24 Tamtéž, s. 96. 


\section{Nedèle Paschy: Kristus vstal z mrtvých! V pravdě vstal z mrtvých!}

Vyvrcholení slavení Velikonoc začíná večer ze soboty na neděli slavnostním průvodem kolem chrámu s jitřní bohoslužbou. Nejprve se věřící shromáždí před chrámem, aby následně otevřené dveře symbolizovaly vstup do nového života. Slavnostní průvod s korouhvemi a ikonami, s rozžatými svícemi věřících, doprovází zpěv: „Vzkříšení tvoje, Kriste Spasiteli, andělé opěvují na nebesích, dejž, abychom i my na zemi čistým srdcem tebe oslavovali!“, načež kněz zvolá: „Kristus vstal z mrtvých!“, po té věřící odpovídají slovy: „Vpravdě vstal z mrtvých!“‘, za kterými následuje známý tropar ${ }^{25}$ : „Vstal Kristus z mrtvých, smrtí smrt překonal a jsoucím ve hrobech život daroval.“

V průběhu nedělního dne Velikonoc, Přechodu, Paschy, je oslavováno vzkř́šení četbou evangelia v několika jazycích, aby byla zvěst šířena ke všem národům. Setkání se Vzkř́í̌eným přináší duchovní radost a pravý pokoj, jak je uvedeno v následném velikonočním kondaku:

Když sestoupil jsi až do hrobu, Nesmrtelný, tehdy jsi přemohl moc podsvětí a vstal jsi z mrtvých jako vítěz, Kriste Bože, ženám myronosicím zvěstuješ: „Radujte se!“ Svým apoštolům uděluješ pokoj a kleslým skýtáš vzkříšení.

Vladimír Losskij v Eseji o mystické teologii Východni Církve k vykupitelskému dílu Krista napsal:

Dílo vykonané Kristem se vztahuje k naší přirozenosti, která není více oddělená od Boha kvůli hříchu. Je novou přirozeností, obnoveným stvořením, které se zjevilo ve světě, novým tělem, čistým od každého vlivu hříchu, svobodným od vnějších závislostí, odděleným od naší nepravosti, od každé cizí vůle, a to skrze drahocennou Krev Krista. ${ }^{26}$

Zvěstování o vzkřríšení je počátek mystického výstupu a cesty sjednocení (via unitiva) s dokonalým boholidstvím Krista. Je prožitek vlastního vzkříšení ve Vzkřrišeném, jak tuto „metamorfózu“ nazval Olivier Clément:

25 Biblická skladba složená z jedné nebo více vět shrnující význam liturgické slavnosti - srov. FARUGGIA, Edward (ed.). Encyklopedický slovnik krestanského Východu, s. 913.

26 LOSSKIJ, Vladimir. Очерк мистического богословия восточной иеркви, s. 117. 
Celý duchovní život lze tedy definovat jako růst „těla pro slávu“ v nás, růst „vnitřního člověka v srdci“, který přebírá celou skutečnost člověka vnějšího s tím, jak se tento člověk vyčerpává a „rozpraskává“ jako kukla, z níž má vyletět motýlek (To je určitě duchovní smysl vrásek). „Mystická smrt“ je uvědomělý sestup do smrti, aby se zde člověk setkal s Kristem a vstoupil do jeho dynamiky vzkřrišení. Aby vědomě prožival naše vzkříšení ve Vzkříšeném (ve staré církvi se mnichovi, jehož askeze došla cíle, říkalo „vzkříšený“). Věčný život tedy začíná už na této zemi, jako předjímání parúzie. ${ }^{27}$

Stejně jako v utrpení nesl Kristus na svém těle tíži celého lidstva, tak i vzkříšení má podle Ignáce IV. rozměr mystického Těla Kristova, které vtahuje nejen jednotlivého člověka, ale též celé lidstvo do reality vzkříšení - a nejen celé lidstvo, nýbrž celý kosmos, který tím vytrhává z potenciálního pádu do chaosu a nicoty. ${ }^{28}$

\section{Závěr}

Slavení tajemství Velikonoc je v centru spirituality křestanství Východu i Západu. Dar poznání dokonalé agapické lásky uzavřené v eucharistii vede člověka k obráceni a pravdivému sebepoznání. Na Velký pátek se věřící setkal s kořenem všeho zla a hříchu, s egoistickou a idolatrickou sebeláskou, konfrontoval se se zradou, zapřením a podlehnutím zlu. Křížovou cestou Ježíše Krista, který na sebe bere následky prvotního hříchu, je člověk vnitřně oćištován a osvojuje si vnitřní postoj pokory a důvěry před temnotou a úzkostí duše. Tajemství Velké soboty je Kristovo sestoupení do předpeklí a Jeho zvěstování, jež osvobozuje od pekla opuštěnosti a zoufalství ve smrti. Spásu očekávající lidé jsou osvíceni zvěstovaným Božím slovem, mohou odvážně nést tíži porušenosti vztahů a participovat na vzkř́íšení. Věřící sjednoceni s boholidstvím Krista se s velikonoční radostí a pokojem účastní na výkupné síle Kristova Vzkříšení. Otevírá se tím nový boholidský život Velikonočni Nedèle, do kterého křestan vstupuje svátostí křtu.

Událost Velikonoc je spásným činem Boží Trojice, která se v každé své Osobě svým svébytným způsobem darovala pro záchranu člověka, aby mohl mít možnost uzdravit svoji hříchem paralyzovanou

27 CLÉMENT, Olivier. Tẻlo pro smrt a pro slávu. Olomouc: Refugium, 2004, s. 124-125.

28 Srov. IGNAZIO IV. L'arte del dialogo. Magnano: Comunità di Bose, 2004, s. 48. 
přirozenost. Uzavřeme nyní meditaci o tajemství Velikonoc v byzantském ritu opětovnou připomínkou trojího paschálního zvolání kněze: „Kristus vstal z mrtvých!“, na které věřící s jistotou odpovídají: „Vpravdě vstal z mrtvých!“

\section{ABSTRACT \\ KAREL SLÁDEK \\ The secret of Easter in the Byzantine rite by means of mystic-theological reflection}

This article interprets the secret of Easter in the Byzantine rite by means of mystic-theological reflection, or by means of spiritual development of a personality as perceived in the Christian mystic tradition. The article is chronologically structured according to the sequence of days of the liturgical period. The method is the application of the teaching of personal spiritual development by means of the path of conversion, purification, enlightenment and unification on individual days of celebrating the secret of Easter in the Byzantine rite. The gift of knowledge of the perfect agape love which is concluded in the Eucharist leads the man to the conversion and truthful self-knowledge. On Good Friday the worshipper meets the root of all evil and sin, the egoistic and idolatry selflove, confronts themself with treachery, renouncement and succumbing to evil. By Jesus Christ's road to Calvary who assumes the consequences of the original sin, the man is internally purified and acquires the inner attitude of humbleness and confidence instead of the darkness and anxiety of the soul. The secret of Holy Saturday is Christ's descending to pre-hell and His Annunciation which liberates from the hell of abandonment and despair in death. People waiting for salvation are enlightened by the announced God's words; they can fearlessly bear the burden of disturbance to relationships and participate in the resurrection. Worshippers unified with Christ's God-humanity participate with Easter joy and peace in the expiating force of Christ's Resurrection. The new God-human life of Easter Sunday is thus opened which a Christian enters through the sacrament of Christening.

\section{Key words}

Easter mysetery, Byzantine rite, mystical theology, spiritual theology, Eucharist 